\title{
Pengaruh Minat Baca dan Penguasaan Kosakata terhadap Kemampuan Menulis Karangan Narasi
}

\author{
Yuliana \\ Universitas Indraprasta PGRI \\ Jalan Nangka No. 58 C/TB. Simatupang, Tanjung Barat, Jakarta Selatan 12530 \\ iyo3ng@gmail.com
}

\begin{abstract}
This research is quantitative research which aims to determine the effect of reading interest and mastery of vocabulary the ability to write narrative essays. The population in this study were class XI students of Nenegri 1 Gunung Putri Vocational School, SMK Negeri 1 Cileungsi, and SMK Negeri 1 Cariu, Bogor Regency. In this study the sampling was done by the proportional random sampling technique. The sample used was 100 students. Data collection is done by distributing questionnaires and questionnaires. The results of this study indicate that: 1) There is a significant effect of reading interest and vocabulary mastery together on the narrative writing ability of students of State Vocational Schools in Bogor Regency. This is evidenced by the acquisition of the Sig. = $0.048<0.05$ and $F_{h}=2.766$. Together the influence of reading interest and vocabulary mastery contributed $32 \%$ to the ability to write narrative essays. 2) There is a significant effect of reading interest on the ability to write narrative essays of students of State Vocational Schools in Bogor Regency. This is evidenced by the acquisition of the Sig. $=0.048<0.05$ and thitung $=2.006 .3)$ There is a significant effect of vocabulary mastery on the ability to write narrative essays of students of State Vocational Schools in Bogor district. This is evidenced by the acquisition of Sig. $=0.033<0.05$ and thitung $=2.116$.
\end{abstract}

Keywords: reading interest, vocabulary mastery, writing ability, narrative composition.

\begin{abstract}
Abstrak
Penelitian ini merupakan penelitian kuantitatif yang bertujuan untuk mengetahui pengaruh minat baca dan penguasaan kosakata terhadap kemampuan menulis karangan narasi. Populasi dalam penelitian ini adalah siswa kelas XI SMK Nenegri 1 Gunung Putri, SMK Negeri 1 Cileungsi, dan SMK Negeri 1 Cariu Kabupaten Bogor. Dalam penelitian ini pengambilan sampel dilakukan dengan teknik proposional random sampling. Sampel yang digunakan sebanyak 100 siswa. Pengumpulan data dilakukan dengan penyebaran angket dan kuesioner. Hasil penelitian ini menunjukkan bahwa: 1) Terdapat pengaruh yang signifikan minat baca dan penguasaan kosakata secara bersama-sama terhadap kemampuan menulis narasi siswa SMK Negeri di Kabupaten Bogor. Hal ini dibuktikan dengan perolehan nilai Sig. $=0,048<0,05$ dan $\mathbf{F}_{\mathrm{h}}=2,766$. Secara bersama-sama pengaruh minat baca dan penguasaan kosakata memberikan kontribusi sebesar 32\% terhadap kemampuan menulis karangan narasi. 2) Terdapat pengaruh yang signifikan minat baca terhadap kemampuan menulis karangan narasi siswa SMK Negeri di Kabupaten Bogor. Hal ini dibuktikan dengan perolehan nilai Sig. $=0,048<0,05$ dan $t_{\text {hitung }}=2,006.3$ ) Terdapat pengaruh yang signifikan penguasaan kosakata terhadap kemampuan menulis karangan narasi siswa SMK Negeri di kabupaten Bogor. Hal ini dibuktikan dengan perolehan nilai Sig. $=0,033<0,05$ dan $\mathbf{t}_{\text {hitung }}=2,116$.
\end{abstract}

Kata Kunci: minat baca, penguasaan kosakata, kemampuan menulis, karangan narasi 


\section{PENDAHULUAN}

Bahasa merupakan sistem tanda bunyi ujaran yang bersifat arbitrer atau sewenang-wenang. Bahasa digunakan untuk menyimbolkan pikiran dan perasaan manusia agar dapat menyampaikan arti kepada orang lain. Bahasa merupakan salah satu elemen penting dalam berkomunikasi. Hal ini menunjukkan bahwa tanpa bahasa, komunikasi tidak dapat dilakukan dengan baik dan interaksi sosial pun tidak pernah terjadi.

Tanpa bahasa, seseorang tidak mampu mengekspresikan dan menyampaikan suatu pesan kepada orang lain. Dalam berkomunikasi terdapat beragam tujuan yang bervariasi di dalamnya, seperti untuk mendapatkan informasi, untuk menjalin kekerabatan, atau untuk melakukan transaksi perdagangan, seperti halnya di era sekarang ini.

Manusia mempergunakan bahasa sebagai sarana komonikasi vital dalam hidup ini. Bahasa adalah milik manusia. Bahasa adalah salah satu ciri pembeda utama manusia dari makhluk hidup lainnya di dunia ini (Tarigan, 2011; 8). Dengan demikian, bahasa memiliki peranan penting dalam kegiatan berkomonikasi, baik lisan maupun tulisan. Dengan bahasa, seseorang dapat mengutarakan keinginan, menjelaskan ide, mengungkapkan pikiran dan gagasannya pada orang lain. Dengan bahasa pula seseorang dapat saling memahami perasaan dan mencurahkan gagasan pikiran dalam bentukn tulisan atau karya tulis, pembelajara bahasa Indonesia di sekolah-sekolah bertujuan agar siswa terampil dalam berbahasa yang meliputi keterampilan menyimak, berbicara, membaca, dan menulis.

Keempat keterampilan berbahasa tersebut saling berkaitan satu dengan yang lain, keterampilan menyimak harus dikuasai karena dengan kegiatan menyimak , seseorang dapat mengenal bunyi-bunyi yang membedakan arti, memeroleh kosakata, dan mengetahui gramatikal. Keterampilan berbicara juga dikuasai seseorang melalui kegiatan menyimak yang telah mengenal bunyi-bunyi serta kosakata dan tata bahasa. Keterampilan membaca harus dimiliki setiap orang karena melalui membaca seseorang memeroleh kosakata baru yang membantu memperkaya perbendaharaan kata sehingga lebih terampil. Semaki banyak bahan bacaan yang dibaca, semakin banyak pula kosakata yang dimiliki. Apabila minat membaca tinggi, maka siswa akan senang membaca dan pada gilirannya siswa akan memperkaya perbendaharaan kosakatanya sehingga dapat dengan mudah untuk merealisasikan sebuah ide atau gagasan ke dalam sebuah tulisan dengan menggunakan kata-kata yang harmonis yang dapat mewakili maksud dari ide atau gagasannya tersebut. Satu diantara beberapa faktor yang dapat mempengaruhi terwujudnya minat baca yang tinggi adalah penyediaan bahan bacaan dan intensitas membaca siswa yang kurang sehingga mengakibatkan minat baca yang renadah. Kegiatan membaca dapat bermakna dan berkualitas apabila didorong oleh minat baca yang tinggi. Minat baca yang rendah diduga sebagai pemicu rendahnya penguasaan kosakata.

Dari keempat keretampilan berbahasa tersebut, keterampilan menulis merupakan proses paling akhir yang menuntut kemampuan berpikir. Kesulitan menulis selalu menjadi masalah bagi semua orang. Keterampilan menulis sangat 
penting bagi semua elemen pendidikan seperti pelajar, mahasiswa, guru, dan dosen sebagai alat komonikasi tulis.

Hal yang sering menjadi kendala dalam menulis adalah kurangnya penguasaan kosakata, padahal kosakata menentukan seberapa terampil sesorang dalam berbahasa. Seperti yang diungkapkan Tarigan (2011: 2), kualitas keterampilan berbahasa seseorang jelas bergantung kepada kuantitas dan kualitas kosakata yang dimilikinya. Semakin kaya kosakata yang kita miliki, maka semakin besar pula kemungkinan kita terampil berbahasa.

Keterampilan menulis perlu mendapat perhatian yang lebih besar dibandingkan ketiga keterampilan berbahasa yang lain. Salah satu cara yang dapat dilakukan untuk menumbuhkan dan mengembangkan kemampuan menulis adalah meningkatkan penguasaan kosakata yang diperoleh dengan kegiatan membaca.

Keterampilan menulis merupakan kegiatan menuangkan ide dan gagasannya dalam bentuk tulisan. Dalam menuangkan ide dan gagasan, tentu seseorang tidak mungkin menulis secara sembarang. Artinya, seorang penulis memerlukan kemampuan mengintrespetasikan gagasannya ke dalam bentuk tulisan yang mudah dipahami pembaca. Pemilihan kosakata yang tepat akan membantu pembaca memahami makna dari tulisan tersebut.

Kegiatan menulis memang bukan hal yang mudah, dan kemampuan menulis tidak datang sendirinya, namun dibutuhkan latihan. Kurangnya latihan menulis oleh siswa SMK Negeri di Kabupaten Bogor menyebabkan mereka kesulitan dalam menuangkan ide dan gagasannya dalam bentuk tulisan. Mengingat pentingnya kegiatan menulis bagi siswa SMK Negeri di kabupaten Bogor, maka sudah sewajarnya pengajaran menulis dibina dengan sebaik-baiknya. Kemampuan ini memungkinkan mereka untuk menuangkan dan mengomunikasikan ide dan gagasan, penghayatan dan penglamannya kepada berbagai pihak terlepas dari kesamaan waktu dan tempat dengan pihak-pihak lain.

Dalam keterampilan menulis kita mengenal 5 jenis karangan, yaitu narasi, deskripsi, eksposisi, argumentasi dan persuasi. Pada narasi gaya penulisannya adalah bercerita. Deskripsi adalah bentuk penulisan yang menggambarkan suatu objek. Sementara itu, eksposisi adalah jenis tulisan yang berisi paparan atau uraian. Argumentasi adalah penulisan yang berisi pendapat sedangkan persuasive adalah penulisan yang bersifat membujuk.

Narasi terbagi menjadi dua jenis, yaitu narasi fiksi dan narasi non fiksi. Biasanya pada narasi, siswa masih banyak menemui kesulitan dalam menuangkan ide atau gagasan. Kesulitan yang sering sekali dialami siswa yakni menentukan kalimat awal dan penggunaan kosakata yang tepat dalam menuangkan ide atau gagasannya. Hal tersebut sesungguhnya dapat diatasi jika siswa banyak melakukan kegiatan membaca, sehingga dengan mudahnya mereka dapat menggunakan kata yang bervariasi dan harmonis dalam menuangkan ide atau gagasannya.

\section{Kemampuan Menulis Karangan Narasi}

Menurut Chaplin (2001:37), “ability (kemampuan, kecakapan, ketangkasanm bakat, kesanggupan) merupakan tenaga (daya kekuatan) untuk melakukan suatu perbuatan." Kemampuan adalah kesanggupan; kecakapan, dan kekuatan. Seseorang dikatakan memiliki kemampuan apabila ia memiliki 
kesanggupan, kecakapan, atau kekuatan untuk melakukan suatu tindakan (performance) sebagai hasil pembawaan dan latihan. Kemampuan seseorang dapat memberikan hasil yang positif ketika dituangkan melalui keterampilan. Keduanya dapat mempermudah seseorang dalam menyelesaikan pekerjaannya sehingga akan mendapatkan hasil yang maksimal. Dengan demikian, kemampuan adalah gambaran kualitatif yang harus dimiliki oleh individu untuk mencapai tujuan yang dipersyaratkan sesuai dengan kondisi yang diharapkan. Hubungannya dengan kegiatan belajar, kemampuan merupakan suatu kekuatan atau kecakapan tertentu yang dimiliki seseorang sebagai hasil pengalamannya dalam kegiatan belajar.

Morsey (dalam Tarigan, 2008: 4) mengatakan, "menulis dipergunakan melaporkan/ memberitahukan, dan memengaruhi; dan maksud serta tujuan seperti itu hanya dapat dicapai dengan baik oleh orang-orang yang dapat menyusun pikirannya dan mengutarakannya dengan jelas, kejelasan ini bergantung pada pikiran, organisasi, pemakaian kata-kata, dan struktur kalimat". Menulis merupakan penyampaian sebuah informasi dengan menggunakan kata dan struktur kalimat yang dapat mewakili ide atau gagasan penulis. Finoza (2008:192) mengemukakan bahwa karangan merupakan hasil akhir dari pekerjaan merangkai kata, kalimat, dan alinea untuk menjabarkan dan mengulas topik dan tema tertentu.

Menurut Keraf (2001:2) pengertian karangan adalah bahasa tulis yang merupakan rangkaian kata demi kata sehingga menjadi sebuah kalimat, paragraf, dan akhirnya menjadi sebuah wacana yang dibaca dan dipahami. Dengan demikian, dapat disimpulkan bahwa karangan merupakan rangkaian kata yang membentuk sebuah kalimat dan alinea sehingga menjadi sebuah paragraf yang menjabarkan suatu topik untuk dibaca dan dipahami oleh para pembaca. Karangan memiliki beberapa jenis, diantaranya, karangan narasi, deskripsi, argumentasi, eksposisi, dan persuasi.

\section{Minat Baca}

Minat baca merupakan keinginan/kecenderungan hati untuk membaca. Tersedia sarana dan prasarana dalam membaca, mampu menumbuhkan kebiasaan membaca. Minat baca dapat dipupuk, dibina, dan dikembangkan karena minat baca adalah keterampilan yang diperoleh setelah seseorang dilahirkan, dan bukan bawaan. Sutarno (2003:19) menjelaskan bahwa minat baca adalah kecenderungan hati yang tinggi terhadap suatu bacaan. Seseorang yang memiliki kecenderungan hati yang tinggi terhadap bacaan, berarti memiliki minat baca yang tinggi. Seseorang yang memiliki minat baca yang tinggi mengagedakan kegiatan membaca, dan menjadikan hal tersebut sebagai suatu kebutuhan. Terkadang mereka menyediakan waktu dan dana khusus untuk membaca dan memperoleh bahan bacaan itu.

Dalyono (2005:182) mengungkapkan bahwa minat baca merupakan kecenderungan jiwa yang mendorong seseorang untuk berbuat sesuatu terhadap membaca. Harus ada dorongan yang kuat untuk menumbuhkan minat membaca seseorang. Dorongan dari dalam diri sendiri akan membuat seseorang senang melakukan kegiatan membaca, nmun jika dorongan itu tidak timbul dari dalam diri sendiri maka tidak akan muncul minat baca. Minat baca terbagi menjadi dua, yaitu: (1) minat membaca spontan, kegiatan membaca yang dilakukan atas dasar kemauan

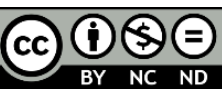


atau inistiatif sendiri, tanpa pengaruh dari pihak luar/pihak lain. (2) minat baca terpola, yaitu kegiatan membaca yang dilakukan sebagai hasil atau akibat pengaruh langsung dan disengaja melalui serangkaian tindakan dan program yang terpola, terutama kegiatan belajar mengajar di sekolah. Minat baca spontan dan minat baca terpola, keduanya sama baiknya dan dapat dipilih sesuai dengan tujuan kita dalam membaca.

\section{Penguasaan Kosakata}

Banyak definisi kosakata yang dikemukakan para ahli bahasa. Pendapat ahli yang satu dengan ahli yang lainnya mungkin berbeda, tetapi banyak pula persamaannya. Pengertian kosakata menurut Keraf (1996: 64) dapat dilihat dari dua segi. Pertama, dari segi bahasa itu sendiri, yang menyatakan bahwa kosakata adalah keseluruhan kata yang dimiliki oleh sebuah bahasa yang merupakan komponen bahasa yang memuat semua informasi tentang makna dan pemakaian kata dalam bahasa. Kedua, dilihat dari segi pemakai bahasa, kosakata adalah kekayaan kata yang dimiliki seseorang pembicara atau penulis. Hal itu sejalan dengan pendapat Nurgiyantoro (2012: 338) yang menyebutkan kosakata adalah kekayaan kata yang dimiliki oleh (terdapat dalam) suatu bahasa.

Kridalaksana dalam Tarigan (1985: 446) mengemukakan bahwa kosakata adalah: a) Komponen bahasa yang memuat semua informasi tentang makna pemakaian kata dalam bahasa; b) Kekayaan kata yang dimiliki seorang pembicara, penulis, atau suatu bahasa; c) Daftar kata yang disusun seperti kamus, tetapi dengan penjelasan yang singkat dan praktis.

Hastuti, dkk (dalam Pramudyantoro, 2000:10) menyebutkan bahwa kosakata atau vokabuler yang disebut juga perbendaharaan kata adalah kata-kata yang terdapat dalam suatu bahasa. Kadang-kadang kosakata diartikan sebagai kata yang disusun secara alfabetis yang disebut glosari.

\section{METODE}

Penelitian ini bersifat deskriptif korelasional. Jenis penelitian ini biasanya melibatkan ukuran statistik/tingkat hubungan yang disebut dengan korelasi (Mc Millan dan Schumacher, dalam Syamsuddin dan Vismaia, 2006:25). Penelitian korelasional menggunakan instrumen untuk menentukan apakah, dan untuk tingkat apa, terdapat hubungan antara dua variable atau lebih yang dapat dikuantitatifkan.

Metode yang digunakan dalam penelitian kuantitatif ini adalah metode survei dengan analisis korelasional. Survei pada dasarnya merupakan pemeriksaan secara teliti tentang fakta atau fenomena perilaku dan sosial terhadap subyek dalam jumlah besar. Dalam riset pendidikan, survei bukan semata-mata dilakukan untuk mengumpulkan data atau informasi, seperti tentang pendapat atau sikap, tetapi juga untuk membuat deskripsi komprehensif maupun untuk menjelaskan hubungan antara berbagai variable yang diteliti. Studi survei adalah salah satu pendekatan penelitian yang pada umumnya digunakan untuk pengumpulan data yang luas dan banyak (Arikunto, 2006:113). Survei adalah penelitian yang mengambil sampel dari satu populasi dan menggunakan kuesioner sebagai alat mengumpulkan data. 
Populasi dalam penelitian ini adalah siswa kelas XI SMK Nenegri 1 Gunung Putri, SMK Negeri 1 Cileungsi, dan SMK Negeri 1 Cariu Kabupaten Bogor. Adapun jumlah populasi dalam penelitian ini sebanyak 965 siswa SMK Negeri Kabupaten Bogor. Dengan memperhatikan populasi yang lebih dari 100 orang, maka penarikan sampel dalam penelitian ini menggunakan sampel secara acak (Random sampling).

Teknik pengambilan sampel menggunakan rumus Taro Yamane sehingga sampel yang digunakan dari 965 maka diperoleh jumlah 100 orang. Adapun anggota sampel yang digunakan oleh peneliti meliputi siswa kelas XI dari 3 SMK Negeri di Kecamatan Cileungsi, Gunungputri dan Cariu Kabupaten Bogor Jawa Barat. Teknik sampling adalah pengambilan sampel dimana setiap angota populasi mendapatkan kesempatan yang sama untuk menjadi anggota sampel. Peneliti dala hal ini menggunakan cluster random sampling karena pengambilan anggota sampel dari populasi didasarkanpada klusternya bukan pada individunya.

\section{Teknik Analisis Data}

Analisis data penelitian dilakukan dengan menggunakan statistic deskriptif dan statistic inferensial. Statistic deksriptif digunakan untuk memperoleh gambaran karakteristik penyebaran skor setiap perubahan yang diteliti dengan menghitung rata-rata, simpangan baku, mean, median dan modus, sedangkan statistic inferensial digunakan untuk menguji hipotesis dengan menggunakan teknik analisis regresi dan korelasi sederhana, serta teknik analisis korelasi dan regresi ganda. Sebelum pengujian hipotesis terlebih dahulu dilakukan pengujian persyaratan analisis yang terdiri dari uji normalitas dan linieritas.

\section{Uji Persyaratan Analisis}

Untuk data dari keterampilan menulis karangan narasi, minat baca, dan penguasaan kosakata, uji persyaratan analisis datanya meliputi Uji Normalitas dan Uji Linieritas.

Untuk menguji apakah data sampel yang sedang diteliti berasal dari populasi dengan distribusi normal atau tidak, dilakukan uji normalitas dengan menggunakan uji Kolmogorov-Smirnov dengan pendekatan korelasi Liliefors.

\section{Uji Hipotesis}

Setelah keseluruhan uji persyaratan analisis data dipenuhi dan diketahui data layak untuk diolah lebih lanjut, maka langkah berikutnya adalah menguji masing-masing hipotesis yang telah diajukan. Pengujian hipotesis menggunakan teknik kolerasi partial dan korelasi ganda, serta regresi linier sederhana dan regresi regresi linier ganda. Adapun kriteria pengujiannya melalui Analisis Korelasi dan Analisis Regresi. 


\section{HASIL DAN PEMBAHASAN}

\section{Hasil}

Terdapat pengaruh yang signifikan minat baca dan penguasaan kosakata secara bersama-sama terhadap kemampuan menulis karangan narasi siswa SMK Negeri di Kaputaen Bogor. Hal ini dibuktikan dengan perolehan nilai Sig. $=0,048$ $<0,05$ dan $F_{\text {hitung }}=2,766$. Terdapat pengaruh yang signifikan minat baca terhadap kemampuan menulis karangan narasi siswa SMK Negeri di Kabupaten Bogor. Hal ini dibuktikan dengan perolehan nilai Sig. $=0,048<0,05$ dan $\mathbf{t}_{\text {hitung }}=2,006$. Terdapat pengaruh yang signifikan penguasaan kosakata terhadap kemampuan menulis karangan narasi siswa SMK Negeri di Kabupaten Bogor. Hal ini dibuktikan dengan perolehan nilai Sig. $=0,033<0,05$ dan $\mathbf{t}_{\text {hitung }}=2,116$.

Dari deskripsi data setelah dilakukan analisis korelasi diperoleh koefisien korelasi sebesar 0,232, setelah dilakukan pengujian dengan program SPSS terbukti bahwa koefisien korelasi tersebut signifikan. Hal ini berarti bahwa terdapat pengaruh variabel bebas minat baca $\left(\mathrm{X}_{1}\right)$ dan penguasaan kosakata $\left(\mathrm{X}_{2}\right)$ secara bersama-sama terhadap variabel terikat kemampuan menulis karangan narasi (Y).

Dari analisis regresi diperoleh persamaan garis regresi $\hat{\mathbf{Y}}=\mathbf{7 3 , 5 2 7}+\mathbf{0 , 1 5 5 X _ { 1 }}$ $+\mathbf{0 , 2 7 6} \mathrm{X}_{2}$. Nilai konstanta $=73,527$ menunjukkan bahwa siswa dengan minat baca dan penguasaan kosakata yang rendah sulit untuk bias mendapatkan kemampuan menulis karangan narasi yang baik, sedangkan nilai koefisien regresi sebesar 0,155 dan 0,276 menunjukkan bahwa terdapat pengaruh positif variabel bebas minat baca $\left(\mathrm{X}_{1}\right)$ dan pengaruh kosakata $\left(\mathrm{X}_{2}\right)$ secara bersama-sama terhadap variabel terikat kemampuan menulis karangan narasi (Y). Setelah dilakukan pengujian linieritas garis regresi dengan menggunakan program SPSS diperoleh bahwa garis regresi tersebut linier.

Dari pengujian signifikansi koifisien regresi yang juga dilakukan dengan program SPSS diperoleh bahwa koifisien regresi tersebut signifikan, yaitu ditunjukkan oleh nilai Sig. $=0,048<0,05$ dan $\mathbf{F}_{\mathrm{h}}=2,766$ maka regresi tersebut signifikan, yang berarti benar bahwa terdapat pengaruh yang positif variabel bebas minat baca (X1) dan penguasaan kosakata (X2) secara bersama-sama terhadap variabel terikat kemampuan menulis karangan narasi $(\mathrm{Y})$.

Pembinaan minat baca dan kebiasaan membaca merupakan usaha jangka panjang yang harus dimulai sedini mungkin. Untuk mendapatkan minat atau kegemaran membaca tidak dapat dicapai secara mendadak melainkan butuh proses dalam bentuk penanaman dan pembiasaan yang bersinambungan. Untuk melatih kebiasaan membaca dituntut adanya kemauan yang kertas dan disiplin yang tinggi serta konsentrasi, baik pikiran maupun perhatian yang baik. .

Minat baca adalah perhatian atau kesukaan seseorang untuk membaca sehingga memotivasi seseorang untuk selalu berhubungan secara aktif dengan bacaan-bacaan yang menarik. Dengan minat baca, siswa dapat lebih mudah dalam memahami materi pembelajaran. Selain itu, perbendaharaan kosakata yang dimiliki oleh siswa akan semakin banyak. 
Penguasaan kosakata siswa berpengaruh dalam meningkatkan kemampuan menulis karangan narasi. Dengan adanya penguasaan kosakata yang baik, siswa tidak akan merasa kesulitan untuk memulai menulis. Kekayaan kosakata yang dimiliki dapat memberikan daftar fariasi kata yang dapat digunakan untuk menuangkan sebuah ide atau gagasan di dalam sebuah tulisan.

\section{Pembahasan}

Kemampuan sering diartikan secara sederhana sebagai kecerdasan. Para peneliti tentang perbedaan individual dalam belajar mengasumsikan bahwa kecerdasan adalah kemampuan dalam belajar. Kemampuan umum didefinisikan sebagai prestasi komparatif individu dalam berbagai tugas, termasuk memecahkan masalah dengan waktu yang terbatas. Lebih jauh dari itu kemampuan juga meliputi kapasitas individu untuk memahami tugas, dan menemukan strategi pemecahan masalah yang cocok, serta prestasi individu dalam sebagian besar tugas-tugas belajar.

Kemampuan dapat juga diartikan dalam pengertian daya sanggup dan pemahaman. Selain itu, kemampuan menyangkut pula tingkat kesiapan dalam menggapai dan memahami suatu hal. Kemampuan adalah penguasaan seseorang terhadap suatu hal yang telah dipelajarinya. Dalam KBBI edisi Ketiga mampu artinya kuasa (bisa, sanggup) melakukan sesuatu, sedangkan kemampuan adalah kesanggupan; kecakapan; kekuatan. Dengan demikian, kemampuan adalah kesanggupan atau kecakapan melakukan sesuatu.

Menulis merupakan kegiatan menuangkan pikiran dan ide-ide melalui tulisan dengan tujuan tertentu. Menurut Tarigan (2008: 3), menulis merupakan keterampilan berbahasa yang dipergunakan untuk berkomunikasi secara tidak langsung, tidak secara tatap muka dengan orang lain. Menulis merupakan kegiatan yang produktif dan ekspresif. Dikatakan keterampilan berbahasa yang produktif dan ekspresif karena menulis dapat mengeksplor penulis untuk mengeluarkan semua ide, gagasan, perasaan, maupun pendapatnya melalui tulisan. Walaupun tidak bertemu secara tatap muka, tapi komunikasi tetap terjalin antara penulis dengan pembaca melalui bahasa tulis.

Menulis merupakan satu kegiatan yang diperlukan di era modern seperti ini. Keterampilan menulis bisa dikatakan sebagai satu ciri dari orang yang terpelajar atau bangsa yang terpelajar. Untuk menjadi seorang penulis yang baik, terlebih dahulu penulis harus menentukan maksud dan tujuan penulisannya, agar pembaca memahami kemana arah tujuan penulisan itu sendiri. Kemudian harus dilihat juga kondisi pembaca, artinya tulisan ini ditujukan kepada pembaca yang bagaimana (dalam hal usia, pengetahuan, minat), sehingga tulisan yang dibuat menjadi suatu karya yang berguna (Suriamiharja, dkk, 1996: 1-2).

Liliawati (dalam Sanjaya, 2005:77) mengartikan minat membaca sebagai suatu perhatian yang kuat dan mendalam disertai dengan perasaan senang terhadap kegiatan membaca sehingga dapat mengarahkan seseorang untuk membaca dengan kemauan sendiri. Seseorang yang memiliki perhatian dan perasaan senang dengan kegiatan membaca dapat dikatakan mempunyai minat baca. Ia akan mengerahkan kemauannya ke dalam kegiatan membaca. Minat membaca memang bersifat individu, tetapi bias ditularkan. Seseorang yang memiliki minat baca yang tinggi, 
dapat menularkan minat bacanya pada teman dekat, teman sekelas atau teman satu sekolahnya. Mereka dapat melakukan kegiatan itu bersama-sama. Ditambah lagi dengan adanya buku yang banyak dan bervariasi, dapat membantu menciptkan budaya literasi, yang memberikan motivasi bahwa membaca itu kegiatan yang menyenangkan dan memberikan banyak manfaat. Selain itu kesempatan yang diberikan guru/sekolah juga pemberian reward merupakan salah satu faktor yang dapat digunakan untuk membudayakan kegiatan literasi di sekolah. Hal tersebut sebaiknya tidak hanya diperhatikan oleh pihak sekolah saja, melainkan keluarga yang juga turut membiasakan kegiatan membaca dengan menciptakan lingkungan yang kondusif untuk membaca, sehingga memungkinkan minat baca seseorang akan timbul.

Ada beberapa faktor yang dapat mempengaruhi minat baca seseorang, yaitu: 1). Faktor internal, yaitu faktor yang berasal dari dalam diri siswa itu sendiri. 2). Faktor eksternal, yaitu faktor yang berada di luar diri siswa, seperti keluarga, lingkungan, dan sekolah.

Kosakata merupakan komponen bahasa yang memuat daftar kata-kata beserta batasannya penggunaannya sesuai dengan fungsinya. Dengan demikian semua bentuk kata, seperti kata dasar, kata berimbuhan, kata ulang, kata majemuk, peribahasa, antonim, dan sinonim yang terdapat dalam bahasa Indonesia termasuk kosakata bahasa Indonesia.

Kosakata bahasa Indonesia semakin bertambah sejalan dengan perkembangan masyarakat dan lingkungan hidup. Begitu pula dengan pesatnya perkembangan dan kemajuan di segala bidang ilmu pengetahuan yang tentunya dapat memperkaya atau memperluas kosakata. Dengan demikian perkembangan kosakata sangat dinamis sesuai dengan tuntutan dan perkembangan kebutuhan pemakainya.

Penguasaan kosakata bukanlah keterampilan yang sederhana, karena mencakup pengenalan, pemilihan, dan penerapan. Penguasaan kosakata juga bukan merupakan proses yang spontan, melainkan proses menuju penguasaan kosakata secara baik dan benar.

\section{SIMPULAN}

Berdasarkan hasil penelitian ini, dapat ditunjukkan bahwa adanya sebuah pengaruh terhadap kemampuan menulis karangan narasi secara bersama-sama oleh minat baca dan penguasaan kosakata.

Untuk itu, penulis menyarankan kepada guru umumnya dan guru Bahasa Indonesia khususnya untuk menumbuhkan minat baca siswa seharusnya dilakukan oleh sekolah khususnya guru Bahasa Indonesia agar dapat meningkatkan kemampuan menulis karangan narasi. Hendaknya dalam pembelajran para guru menerapkan berbagai model pembelajaran yang pariatif guna menarik minat siswa untuk menambah perbendaharaan kosakata. Orang tua juga berperan aktif dalam rangka meningkatkan minat baca dan penguasaan kosakata ketika siswa berada di luar sekolah, mulai dari sarana penunjang dalam penguasaan materi di sekolah 


\section{DAFTAR PUSTAKA}

Arikunto, S. (2006). Prosedur penelitian suatu pendekatan praktik. Jakarta: Rineka Cipta.

Chaplin, J. P. (2001). Kamus lengkap psikologi (terjemahan Kartini Kartono). Jakara: Raja Graindo Perkasa.

Dalyono, M. (2005). Prestasi belajar. Jakarta: Rineka Cipta.

Finoza, L. (2008). Komposisi bahasa Indonesia. Bandung: Diksi Insan Mulia.

Keraf, G. (2001). Argumentasi dan narasi. Jakarta: Gramedia Pustaka Utama.

Keraf, G. (1996). Kosa kata bahasa Indonesia. Jakarta: Gramedia Pustaka Utama.

Nurgiyantoro, B. (2012). Teori pengkajian fiksi. Yogyakarta: Gajah Mada University Press.

Pramudyantoro. (2000). Penggunaan kosakata bidang ilmu pengetahuan alam dan teknologi dalam karangan siswa kelas II SMU Muhammadiyah V Yogyakarta. Universitas Negeri Yogyakarta.

Sanjaya, W. (2005). Penelitian tindakan kelas. Jakarta: Kencana Prenada Media Grup.

Suriamiharja, A. dkk. (1996). Petunjuk Praktis Menulis.

Suriamiharja, A., Husen, A., \& Nurjanah, N. (1996). Petunjuk praktis menulis. Jakarta: Departemen Pendidikan dan Kebudayaan Direktorat Jenderal Pendidikan Dasar dan Menengah Bagian Proyek Penataran Guru SLTP Setara D-III.

Sutarno, N. S. (2003). Perpustakaan dan masyarakat. Yayasan Obor Indonesia.

Syamsuddin, A. R., \& Vismaia, S. D. (2006). Metode penelitian pendidikan bahasa. Bandung: PT Remaja Rosdakarya.

Tarigan, H. G. (1985). Pengajaran kosakata. Bandung: Angkasa.

Tarigan, H. G. (2008). Menulis sebagai suatu keterampilan berbahasa. Bandung: Penerbit Angkasa.

Tarigan, H. G. (2011). Pengajaran kosakata. Edisi Revisi. Bandung: Angkasa. 